\title{
Re-Adjusting Museum Theoretics (and Hence, Practices) to Include Indigenous Community Needs and Values
}

Re-Ajustando la Teorética de los Museos (y por ende, sus Prácticas) para Incluir las Necesidades y Valores de la Comunidad indígena

Jessie Ryker-Crawford

\section{OpenEdition Journals}

Electronic version

URL: https://journals.openedition.org/iss/3394

DOI: 10.4000/iss.3394

ISSN: 2306-4161

Publisher

ICOM - International Council of Museums

Printed version

Date of publication: 18 December 2021

Number of pages: 134-141

ISBN: 978-92-9012-446-7

ISSN: 2309-1290

Electronic reference

Jessie Ryker-Crawford, "Re-Adjusting Museum Theoretics (and Hence, Practices) to Include Indigenous Community Needs and Values", ICOFOM Study Series [Online], 49-1 | 2021, Online since 18 December 2021, connection on 08 January 2022. URL: http://journals.openedition.org/iss/3394 ; DOI: https://doi.org/10.4000/iss.3394 


\section{Re-Adjusting Museum}

Theoretics ${ }^{1}$ (and

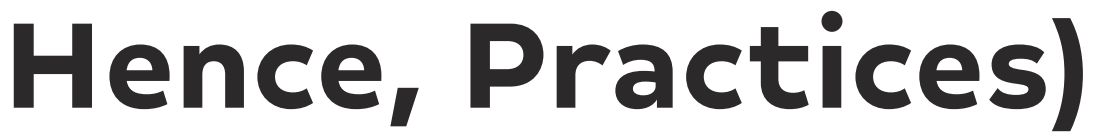

to Include

Indigenous

Community

Needs and Values

Jessie Ryker-Crawford

Institute of American Indian Arts - Santa Fe, USA

\section{ABSTRACT}

Curation and the collections of cultural material must be the result of a collaborative process; beyond being the stewards of cultural objects, we must recognize our positions as servants to the communities to

I. Theoretics (the integral act of applying both theory and hypothesis) ultimately affects the researcher's findings on any given topic. 
whom we owe our livelihoods. The visual discourses embedded in the ways that we curate tangible cultural heritage should strongly reflect the intangibles of the cultural heritage that we collect. This requires new museological theories and, hence, practices that break down previous colonial theories and practices. A case study on peach trees is presented here that highlights what can occur when collaborative models of curation are embraced.

Keywords: museological theories, museological practices, stewards, collaborative models.

\section{RESUMEN}

\section{Re-Ajustando la Teorética de los Museos (y por ende, sus Prácticas) para Incluir las Necesidades y Valores de la Comunidad indígena}

La curaduría y las colecciones de material cultural deben ser un proceso colaborativo; más allá de ser los custodios de los objetos culturales, debemos reconocer nuestra posición como servidores de las comunidades a las que debemos nuestros medios de vida. Los discursos visuales incrustados en las formas en que curamos el patrimonio cultural tangible deben reflejar fuertemente lo intangible del patrimonio cultural que recopilamos. Esto requiere nuevas teorías museológicas y, por ende, prácticas que rompan las teorías y prácticas coloniales anteriores. Aquí se presenta un estudio de caso sobre árboles de durazno (melocotón) que destaca lo que puede ocurrir cuando se adoptan modelos colaborativos de curaduría.

Palabras Clave: museológicas teorías, museológicas prácticas, custodios, modelos colaborativos.

\section{$\star$}

\section{Introduction}

Boozhoo. I would first like to introduce myself, in my language, if I may.

Niin Jessie Ryker-Crawford ndizhinikaaz. Ninisa Anishinaabe, miinawah Gaa-waabaabiganikaag ishkonigan nindonjiibaa; Maang niindoodem.

Greetings. My name is Jessie Ryker-Crawford. I am Chippewa (or, Anishinaabe), and I am of the White Earth Chippewa Nation; I am of the Loon Clan. ${ }^{2}$

2. Dr. Jessie Ryker-Crawford is Chair of the Museum Studies Department and Professor of Museum Studies at the Institute of American Indian Arts in Santa Fe, New Mexico, USA. Her work has 


\section{Land Recognition and Acknowledgement}

I would like to acknowledge the Indigenous Peoples of New Hampshire: the Abenaki, the Maleseet, the Micmac, the Passamaquoddy, the Penobscot, and the Pennacook Nations. And due acknowledgement goes to those who traditionally included New Hampshire lands as a hunting and ecoagricultural region: the Akwesasne, the Kahnawake, the Mahican, the Nipmuck, the Pequot, the Schaghticoke, and the Wampanoag Nations.

If I have overlooked any tribal nations in my acknowledgement, I do beg your forgiveness.

If you are not used to Native American introductions and acknowledgements, the beginning of my presentation may seem a little long. But there is a reason that we take the time to acknowledge and honor those who have brought us to the place where we now stand. It is a way to be humble, and to remember that none of us stand alone in this space that we call "now." Introductions and acknowledgements ground us in the fact that everything we do is a collaborative activity - and it is good to acknowledge those who we can, when we can.

\section{Re-Adjusting Museum Theoretics}

Those of us in the museum field owe our livelihoods and the richness of our professions to others: past museum professionals, peoples of our own, and other cultures. We are much more than simply stewards of inanimate objects that are held within our collections. We are also servants of the cultures and communities from which we gather knowledge, insight, and both personal and professional enlightenment. For we are here to help share the stories that have been for so many years silenced, miscommunicated, disfigured, and misapprehended.

For, as we all know, it is a fact that we can open any publication on the tangible and intangible heritage of other peoples and find a myriad of inaccurate and derogatory descriptions. Or worse, the exposing of sacred Ceremonial knowledge that, because it is now in print, is presented far out of context from the knowledge systems from which it has emerged.

We know that it is a fact that we can, unfortunately, walk into the storage systems of our institutions and find elder-objects that should never have found their way there, and exhibit halls that are presenting material culture that was never meant to be placed on view.

These facts have a great deal to do with anthropological, archaeological, and museological theories and, hence, practices, that have been in place for hundreds of years. For theories lead to practice. And only sound, healthy, inclusionary,

focused upon the Indigenization and decolonization of the museum field. 
and beneficial theories lead to sound, healthy, inclusionary, and beneficial practices.

However, new critical conversations are emerging across these disciplines of ours and others.

We cannot deny that the field of museology originated from colonial theories and practices; theories that have been skewed, grounded in presumptions that some cultures are "higher on the evolutionary scale" while others are "less than." In the words of one of my students and colleagues within the museum field, Alison Guzmán, "Here we are today, centuries later, re-adjusting the museum model to address Indigenous community needs and values, so that [we] may self-represent [ourselves]...and manage [our] own cultural patrimony" (class discussion, April 16, 2020).

Arthur Amiotte, an Oglala Lakota artist and educator, spoke of Native American art, but his words resonate when referring to all objects of cultural value. He states:

The American Indian has tenaciously held on to [their] arts, not in the sense of object alone, but rather as a fabric that binds and holds together many dimensions of [our] very existence. The arts are to [us] an expression of the integrated forces that tie together and unify all aspects of life... [The Native American artist] is therefore, the eyes, ears and voice of [their] own age. More than that, [they are a] personal record which...is the partial repository or the encyclopedia of [our] oral tradition[s]. (Amiotte, 1977, as cited in Hill, 1992, p. 10)

As Native American peoples, we find ourselves de-constructing colonial identities as we negotiate the cultural self in today's world. We are attempting...no, actively undertaking, new ways of presenting identity and cultural continuity as expressed through museum institutions - the collecting of, holding of, and exhibiting of our culture through the presentations and discussions surrounding our tangible and intangible cultural heritage.

Social, historical and political issues are still waiting to be articulated and analyzed incorporating critical anthropology and theoretical approaches to visual discourse and the politics of representation via our objects.

In an attempt to formulate new ways of thinking about issues of concern to the Indigenous peoples of North America, shared ethnographical approaches and inclusionary research methods are required to be utilized and embraced.

\section{Collaborative Curation Case Study: The Peach Trees}

I would like to stop here and tell a story of peach trees. 
For my museology students who are reading this article, I apologize. For they have heard this a number of times now...

A tribal community (who will not be named) reached out to us in the Institute of American Indian Arts Museum Studies Program, ${ }^{3}$ wanting to create a number of mini exhibitions about their community.

Following the methods of collaborative curation ${ }^{4}$ as we do, both faculty and students worked with tribal leaders to put in place a community gathering to discuss possible exhibition themes.

An announcement was sent out to the community, and we asked tribal members who, in their community, could be contracted to prepare a meal that included traditional foods, so that we could first sit down and have a meal together. This is an important traditional meeting methodology of Native American people since before colonial contact.

The New Mexico History Museum and the Maxwell Museum of Anthropology had given the aforementioned tribe full access to their archival collections of images - over 300 high resolution images. We prepared a slide show, in the hopes that the imagery would help to stimulate exhibition ideas.

The gathering included youth and elders, council members and language holders. We began with describing the steps that we follow when building an exhibit, from bouncing off ideas to conducting further research, to choosing objects or images, and to producing exhibit text. We showed a few examples and then began the slide show. The slide show was imperative. Slowly, discussions among the community members arose, with requests to return to certain images, and to pause the slide show at others. The discussions moved into the tribal language, and we respectfully remained silent while discussions were held.

We were very aware that when the discussions moved back into English, it was to include us, faculty and students from other tribes.

The information that came out of those discussions was invaluable.

First of all, a number of the slides were reversed. Having been made on glass plates-many from the 1800s-the photographer had written on the back of

3. The Institute of American Indian Arts (IAIA) is a Native American multi-tribal college based in Santa Fe, New Mexico. Begun in 1962 and accredited by the United States Higher Learning Commission in 1973, IAIA offers Indigenous-based degree programs in studio arts, creative writing, Indigenous liberal studies, cinematic arts, performance arts, and museum studies. Its museum studies program is the oldest museum degree program in the nation. Although focused upon offering Native American student curricula that is specific to Indigenous thought and philosophies, IAIA is open to all students across the world.

4. For more information on theories that pertain to collaborative curation, refer to Lonetree (2OI2), Tuhiwai Smith (1999) and Wilson (2008) in the bibliography. 
the slide, away from the emulsion. So, dancers were shown holding objects in the wrong hand, and ceremonial kivas were shown backward.

The second thing that emerged was a deep discussion of the peach trees that once surrounded the community plaza. Elders remembered these trees that were long since gone, and a discussion of why they no longer existed began between the youth and the elders. A consensus was reached that they had disappeared during the 1930s, when forced governmental housing dictated that new houses built for tribal members be constructed away from the communal plaza and traditional adobe living structures and placed instead on the surrounding reservation lands that were forcibly allotted to each family.

Elders were adamant that, at some point, a large permanent exhibit be produced about the importance of those peach trees to the community.

\section{What We Learned from the Collaborative Process}

This story highlights many things, as stories often do. It helps us to realize and opens up for us the possibilities of curatorial venues that could not have been thought up by those outside of the communities themselves; further research on 1930s-era HUD housing or US Department of Housing and Urban Development housing projects and their impact on traditional lifeways; of the 1600s-era migration of Spain's peoples into the Southwest and both the stories of forced colonization, but also the resilience of Native peoples and integration of important food crops and fruit trees. Of changing times, they are remembered by the elders of a community.

It also highlights that we, as curators, collections managers and museum professionals, have a plethora of stories that we can help share, if we understand that we still hold onto decades-old theories and methodologies of "doing museology" that we may subconsciously be still following.

This story highlights what can emerge when research methodologies and curatorial theoretics are deeply ingrained with the ethics of careful and mindful methods of collaboration. That through these ethical methods, what is yet to be explored is how Native American culture is multifaceted, with internal discourses that are waiting to be shared with outside communities and other cultures as well as within, which can resonate and add to our overall celebration of humanity.

I say multifaceted, because these stories of "self" reflect comparable as well as opposing historical, political and philosophical Native backgrounds. The negotiation of Native American identity operates on many different levels and includes diverse Native perspectives and discursive voices.

What is left to be presented in museums and the stories that they help share is an ethnographical approach to curation as an Indigenous discourse on Native identity itself, reflecting an internal maneuvering and often dialectical response to colonial pressures, both historical and contemporary. 
Let's not forget to include contemporary Native American artwork, which oftentimes addresses cultural, social and political issues that are of relevance and concern to Native communities today and that illustrate an inter-cultural representation of a Native American cultural identity.

For our art is a visual discourse that does not reflect a homogenous presentation of Native identity but rather speaks of unique cultural histories and experiences and pushes back against stereotypical labels generated outside of Native American communities.

For those stereotypes often force Native individuals to politically and ideologically align themselves to arbitrary categories of traditional vs. modern Native identity - a fact that many contemporary Native artists are painfully aware of. This underlying crisis of representation is woven into and throughout contemporary Native American art in various ways, exposing an internal discourse that is at times fragmented and controversial, yet rich in dialogue, which is what we are interested in, in this educational field of ours.

Through the ways in which we conduct our museological practices, which are our collecting, our exhibiting, and our presentation of Native American cultures, we can help answer the questions that we, as Native American people, are struggling with: "How does tradition play within a modern Native identity?"; "How is cultural identity currently being negotiated and re-defined?"; "What experiences have diverse Native American peoples shared throughout the post-contact period?"; and "What can we say about a collective historical experience as well as our distinctive cultural experiences?"

It is these questions that are most often explored internally (and at varying degrees) within our communities. They echo a discourse that has been in place since initial European contact and conquest, and they encompass much broader topics of social crises-assimilation, loss/retainment of culture, power relations, re-definement of self-all set within specific historical contexts and movements.

Decades-old theorems (and hence, practices) have worked to silence stories that are begging to be told. We follow those skewed theories without meaning to. For they are the way that things have always been done.

Going into a community, slowly making strong ties, and listening carefully, without dictating how long that should take or in what direction that might go, can be uncomfortable. For we are not taught methods that work. But they are out there (Abu-Saad \& Champagne, 2006; Bench, 2014; Chilisa, 2012; LaDuke, 2005; Lambert, 2014; Lischke \& McNab, 2005; Lonetree, 2012; Peers \& Brown, 2003; Tuhiwai Smith, 1999; Wilson, 2008).

Collaborative models of research. Indigenous curatorial methods and practices. Indigenous research methodologies. These are tools that are being disseminated by Indigenous professionals and knowledge holders themselves. They reflect a shift in power-play, and all lay the expertise in the hands of the communities 
themselves rather than in the hands of the researcher, the collector, and the museum professional. As it should be.

Let's take our responsibility as stewards and servants to others seriously. Let's break away from the theory that we are the experts. Let's open up the possibilities of aiding in stories waiting to be told, which cannot possibly originate from us. In this way, our coffers of collections and exhibits that we hold for the originating communities, acting as their cultural stewards and servants, can reflect their needs, wants, and values-whoever that community is: tribal, ethnic, under-represented, or mainstream.

Miigwetch. 